Abstracta Iranica

Revue bibliographique pour le domaine irano-aryen

Volume 32-33 | 2013

Comptes rendus des publications de 2009-2010

\title{
Carl Ernst. Fayzi Illuminationist Interpretation of Vedanta: The Shariq al-ma'rifa
}

\section{Fabrizio Speziale}

\section{(2) OpenEdition}

1 Journals

Édition électronique

URL : http://journals.openedition.org/abstractairanica/40625

DOI : 10.4000/abstractairanica.40625

ISSN : 1961-960X

\section{Éditeur :}

CNRS (UMR 7528 Mondes iraniens et indiens), Éditions de l'IFRI

\section{Édition imprimée}

Date de publication : 1 décembre 2013

ISSN : 0240-8910

\section{Référence électronique}

Fabrizio Speziale, «Carl Ernst. Fayzi Illuminationist Interpretation of Vedanta: The Shariq al-ma'rifa », Abstracta Iranica [En ligne], Volume 32-33 | 2013, document 272, mis en ligne le 01 juillet 2016, consulté le 03 octobre 2020. URL : http://journals.openedition.org/abstractairanica/40625 ; DOI : https://doi.org/10.4000/abstractairanica.40625

Ce document a été généré automatiquement le 3 octobre 2020.

Tous droits réservés 


\title{
Carl Ernst. Fayzi Illuminationist Interpretation of Vedanta: The Shariq al-ma'rifa
}

\author{
Fabrizio Speziale
}

\section{RÉFÉRENCE}

Carl Ernst. « Fayzi Illuminationist Interpretation of Vedanta: The Shariq al-ma'rifa ». Comparative Studies of South Asia, Africa and the Middle East 30, 3, 2010, p. 156-64.

Cet article analyse le Šāriq al-ma'rifa, ouvrage attribué à Abū al-Fayḍ 'Faiḍ̂i’' (m. 1004/1595), poète et intellectuel de la cour du souverain moghol Akbar, et frère de l'historien Abū al-Faḍl 'Allamī. Faiḍi collabora à la révision de la traduction persane du Mahābhārata commandée par Akbar et réalisa une adaptation persane de la Līlāvatī, un ouvrage en sanskrit sur l'arithmétique et la géométrie. Le Šāriq al-ma'rifa est un traité en persan sur la philosophie et la mystique hindoues, divisé en douze chapitres. Les deux thèmes principaux abordés dans ce traité sont la figure de Krishna et les enseignements du yoga, telles les pratiques pour le contrôle du souffle. Comme il montre l'A., dans Šāriq al-márifa la traduction persane des concepts hindous est caractérisée par l'utilisation des nombreux termes issus des lexiques išrāqi et soufi. 


\section{AUTEURS}

\section{FABRIZIO SPEZIALE}

Université Sorbonne Nouvelle-Paris 3/Mondes iranien et indien, Paris 